\title{
SOME RATIONALISM ABOUT REALISM
}

\section{HERMANN KANTOROWICZ $\dagger$}

IT should be stressed from the outset that this article is meant as a criticism and is therefore directed exclusively against those sides of the realist movement in American jurisprudence which are open to criticism. I do not intend to give a comprehensive picture of the whole movement, nor do I minimize the admirable achievements of the realists, especially in the field of research. Moreover, I do not deny that my remarks can be criticized on the ground that the realists teach the contrary of what I say they teach. It is indeed one of their weak points that it is possible to find in their writings contradictions of many of their assertions. It will therefore be necessary to give a number of literal quotations in order to prove my criticism, but I know and admit that I could give other quotations to the contrary. These contradictions are to be found in the same author, often even in the same article, still more often in different authors. For the realist movement--and this is another difficulty for the critic-does not form a school or a party; it has no caucus, no boss, no platform, no slogans. It suffices to name some of the adherents in order to realize that one can not expect them to agree. Their senior is the "great dissenter," Oliver Wendell Holmes, and among his followers there are such different personalities as Bingham, Clark, Cook, Frank, Llewellyn, Oliphant, Moore, Patterson, Radin and Yntema. ${ }^{1}$ But nevertheless they agree in two fundamental postulates, one, a substantive postulate regarding the nature of the law, the other, a formal postulate regarding the nature of legal science. It is these fundamental theories alone which $I$ wish to discuss here.

The substantive theory is that the law is not a body of rules but of facts; the formal theory, that legal science is not a rational but an empirical science. I do not assert that these theories are simply untrue; I shall try to show that they are exaggerations of the truth. But the truth is not original. The nucleus of the substantive theory was developed by a Franco-German movement which produced the free law doctrine;

$\uparrow$ Professor of Law, formerly at Kiel University (Germany), now at The New School for Social Research, New York. This article is in substance the same as that read in Professor K. N. Llewellyn's Seminar, Columbia University, in April, 1934.

1. For a bibliography of Legal Realism see Llewellyn, Some Realism about Realism (1931) 44 HaRv. L. Rev. 1222, 1257-1259, with additions in 1 Lleweldys, PraejudizrenRECHT UND RECHTSPRECHUNG IN AMIERIKA (Leipzig 1933) 120 et seq; 2 id. 350 . See the excellent historical survey in Auburtin, Amerikanische Rechtsaufiassung and die Neucren Amerikanischen Theorien der Rechtssoziologie und des Rechtssocialismus (1932) 3 ZEITSCHRIFT FÜR AUSLÄNDISCHES ÖFFENTLICHES RECHT UND VÖLEERRECHT 529-567. 
the nucleus of the formal theory, by a German-American movement known as the sociological school of law. ${ }^{2}$

The free law doctrine teaches (if we may sum up an elaborate system in a few words): The traditional sources of the law, the "formal" law, statutes and precedents, have gaps which must be filled up, must be filled up with law if the decision is to be a judicial decision, and this law must have a general character if equality before the law is to be maintained; the gap-filling material must therefore consist of rules, rules of law. These are "free" law in the sense that they are not formal law: they have not been formalized but are still in a state of transition like bills, principles of policy, business customs, inarticulate convictions, emotional preferences. Many of them are formulated for the purpose of a concrete judicial decision by the courts, acting within their discretion, through acts of will and value-judgments, and constitute therefore judge-made law. Their validity is far less than that of the formal law and sometimes nil, but their practical importance is even greater, because, where the formal law is clear and complete, litigation is not likely to occur. This free law thesis has been exaggerated by those realists who teach that law consists of judicial decisions alone, and therefore of facts.

The sociological school of law teaches that the law must be interpreted according to its aims, that these aims are to be found in its (desirable) .effects on social (including economic) life, and that therefore the law cannot be understood nor applied without the aid of a sociological (including economic) study of social reality. This sociological thesis has been exaggerated by those realists who teach that legal science is itself a sociological, and therefore an empirical science.

Both schools have their fountain-head in Rudolf Jhering. 3 The free law school was developed in France by Geny and his many followers, in Germany (and Austria) by men like Ehrlich, Fuchs, Kohler, Mayer, Radbruch, Sternberg, and Zitelmann. It apparently has no adherents in this country.

The sociological movement has been headed in Germany by Ehrlich, Heck, Hedemann, Nussbaum and the greatest of sociologists, Max Weber; in America by Mr. Justice Brandeis, Mr. Justice Cardozo and Dean Pound. The writer has himself had a certain share in both movements. ${ }^{4}$

2. The most complete bibliography (and history) of both movements is to be found in Gény, Méthodes D'Interprétation Et Sources En Drott Privé Positrf (2d ed. 1919), with additions in Gurvitch, Le Tedrps Présent Ex L'Idée Du Droit Social (1931) 213 . 295.

3. Kantorowicz, Aus Der Vorgeschachte Der Fretrechtsleme (Mannheim 1925) 38 et seq.

4. Cf. TAT UNd Schuld (Zürich 1933) 25 et seq. with bibliography (since 1906). The 
But for the realist exaggerations he is not responsible, although he has sometimes been praised for them. ${ }^{5}$ It is disagreeable enough for a man to have to pay alimony for his own illegitimate issue; but he cannot be expected to pay for other men's bastards, and like it.

Returning to the American counterparts of these two schools of legal thought, let us examine two of these exaggerations, as found in the assertions of the American realists, and point out the strange consequences to which their treatment of both the substantive and the formal theories must lead. Here again, however, it must be admitted that statements of opposite tenor are to be encountered, and even emphasized, in the writings of certain realists, especially in those of Llewellyn, ${ }^{6}$ who notwithstanding his radical bearing, belongs to the moderate group of the movement. ${ }^{7}$ These other statements are to the effect that the law is not exclusively a body of judicial decisions, but also a body of rules, and that legal science is not only a sociological, but also a rational science. However, these moderate views scarcely any one will dispute; they were comparatively new thirty years ago, but are now accepted almost universally -in theory, though not in practice.

The realist movement owes its astonishing growth to the radical theories stated above. These are the doctrines which threaten the quiet progress of science. It cannot, therefore, be considered unfair if I restrict my criticism to the radical theories of the realist movement; other critics such as Adler, Cohen, Dickinson, Fuller, Goodhart and. Dean Pound have done more or less the same. ${ }^{8}$ It is for the realists themselves to avoid such unilateral criticism in the future by changing their "vocal behavior," as they would call it. They should abandon these radical views, confine themselves to voicing their moderate doctrines, and continue, by all means, their excellent research work which does not presuppose their untenable postulates and does not clash with their tenable ones.

\section{The Nature of the Law According to the Realists}

In setting forth the realists' concept of the nature of law, let us adduce a number of typical quotations:

article most easily available for American readers is Kantorowicz, Legal Science-a Summary of its Methodology (1928) 28 CoL. L. Rev. 679, with footnotes by E. W. Patterson.

5. Llewellyn, The Constitution as an Institution (1943) 34 Cor. L. Rev. 1, 10; Book Review (1934) 43 YaLE L. J. 516.

6. See Llewellyn, supra note 1 , at 1241.

7. Fuller, American Legal Realism (1934) 82 U. of PA. L. Rev. 429, 433, 441 n. 26, 450, 460.

8. Adler, Law and the Modern Mind: A Symposium (1931) 31 Coc. L. Rev. S2, 91; Comen, Law And The Soctal Order (1933) 198 et seq, 357 et seq; Dickinson, Legal Rules 
"I use the phrase 'the law' in the sense of sequences of external facts and their concrete legal consequences through the concrete operation of governmental machinery."

"This past behavior of the judges can be described in terms of certain generalizations which we call rules and principles of law."10

"Rules, whether stated by judges or others, whether in statutes, opinions or text-books by learned authors, are not the Law, but are only some among many of the sources to which judges go in making the law of the cases tried before them ... The law, therefore, consists of decisions, not of rules. If so, then, whenever a judge decides a case he is making law."11

"What these officials [the officials of the law] do about disputes is, to my mind, the law itself." 12

". . . the theory that rules decide cases seems for a century to have fooled not only library-ridden recluses, but judges."13

"To say that a legal institution,--private property, the federal government of the United States, Columbia University, - exists is to say that a group of persons is doing something, is acting in some way." 14

The realists' conception of the Law, their substantive thesis, is therefore: the Law is not a body of rules, not an Ought, but a factual reality. It is the real behavior of certain people, especially of the officials of the Law, more especially of the judges who make the Law through their decisions, which, therefore, constitutes the Law.

Before we criticize this theory, one logical observation may be permitted. The discussion, by all means, must not degenerate into a fruitless logomachy - one man understanding by law, this, and another desirous of understanding something else. This question is far more than a terminological dispute. It has momentous consequences. Whatever we define as "law" must be the chief subject among those which the "law" schools teach, or ought to teach; whatever we define as "law" must be the topic, or the chief topic, of the science of "law"; and whatever, in an American discussion, is defined as "law" must be in harmony with positive American Law insofar as it uses the expression "law." Now, for instance, the judge charges a jury on questions of law, not of fact; the error in fact sometimes excuses, the error in law does not;

(1931) 79 U. of PA. L. Rev. 833, 1052 ; Fuller, supra note 7, at 429 et seq.; Goodhart, Some American Interpretations of Law, in JennIngs, Modern TheorIes of Law (1933) 1; Pound, The Call for a Realist Jurisprudence (1931) 44 HARv. L. REv. 697.

9. Bingham, What is the Law? (1912) 11 MrcH. L. Rev. 109, n. 29. Obviously Bingham defines "the law" by the concept of "legal."

10. Cook, Scientific Method and the Law (1927) 13 A. B. A. J. 303, 308.

11. Frank, Law aNd The Modern Mnd (1930) 127-128.

12. Llewellyn, The Bramale Bush (1930) 3. Italics are those of the author quoted.

13. Llewellyn, supra note 5 , at 7 .

14. Moore, The Rational Basis of Legal Institutions (1923) 23 Cor. L. REv. 609. 
appellate jurisdiction is not the same over law as it is over fact. This alone should suffice to show that in the interpretation of American law, and for that matter of European law also, we must distinguish between law and facts. For this reason alone a theory which ignores this distinction by calling only factual behavior "law" breaks down at the outset. But then, how can we explain the commission of such an elementary mistake by distinguished jurists?

The explanation is that it is based on extrajural dogmas, on erroneous assumptions, not about the law but about the philosophy of law. It is, therefore, based mostly on unconscious prejudices, six of which may be pointed out. Fortunately, we can illustrate this connection between the theory and the underlying prejudices by means of literal quotations from Llewellyn, who is as outspoken in his premises as we have seen him to be in his conclusions. The illustrations are confined to the writings of a single author, in view of the indubitable fact that Mr. Llewellyn is considered the most representative among American realists. It ought, however, to be pointed out, that the same views could be traced in the writings of other realists, especially in those of Joseph W. Bingham, Jerome Frank, and Max Radin.

1.

"If rules decided cases, one judge would be as good as another, provided only" the rules had been adduced before him."15

This displays the formalistic prejudice, which, by the way, is common also to many critics of realism. It is a prejudice to believe that the Law consists of nothing but formal law handed down by tradition, and it is fatal to overlook those rules which a judge must form whenever the formal law has a gap. Of course, only the best judges, only lawyers who know more than law, who have thoroughly studied, not only experienced, real economic and social life, its effects and its needs, are capable of conceiving and formulating the proper rules for the concrete cases. One should not object that this would be a task solely for the judge's discretion. Discretion is not opposed to rules, as is usually said; it is an intuitive way of finding rules: those "inarticulate major premises," which must be general if they are to be major premises, and which must be rules of law if they are to serve as major premises for judicial decisions.

2.

"An inch from the eye is a portion of the Text; the whole living world behind is 'covered' by it ... It is institutions which validate the Words, not the Words which validate the institutions . . . To study the Words of a Document ... is to invite inattention to either [governmental] effects or needs."16

15. Llewellyn, supra note 5 , at 7 .

16. Llewellyn, supra note 5 , at 17,35 . 
Here we are faced by the verbalistic prejudice: it is erroneous to believe that the law is the wording of the Law, still more erroneous to believe that it is the printed document. This prejudice overlooks the fact that only the meaning of the Law counts in the decision. But every interpretation, however free and audacious, must be at least compatible with the text, with one of its possible meanings. Here lies the great significance of the language technique as a means of interpreting the wording of statutes and decisions. The frequent attacks on words are therefore unjustified. Whatever the relation of thought to language may be, words are indispensable tools for fixing and communicating legal ideas; even an attack on words must be couched in words. If I myself have rejected the old conception of legal science as that of a Wortreissenschaft, I have meant that the words of the Law must not be considered in the way the professional word scholar, the philologist, considers them. The philologist interprets them as they were subjectively meant, the lawyer as carrying an objective meaning which must be construed by highly technical means. This meaning can remain unaltered even if the words are changed-many rules of English law have been translated from lawFrench without essential alterations of their meanings and vice versaand this shows that the subject-matter with which the lawyer deals is not words but their meanings.

3.

"If rules decided cases, law stood still ... whereas growth and change of law were as striking in nineteenth-and twentieth-century America as they have ever been. . . . At the beginning of a code experiment, intent of the language has a clear and proper bearing on men's actions. . . . The words are thus-at the beginning-best read in terms of the legislative history. . . . But even here, intent cannot rule purely. Some cases have not been put in the debate. Resort must then be had to language and circumstance, to 'obvious' rather than to real intent."17

This is what may be called the historical prejudice. To the historian, of course, the Law is an historical act; its meaning is the original, the "real" intent of the makers of the statute or of the drafters of the decision, and therefore unchangeable like everything that is past. To the jurist the Law is the objective meaning of statute or opinion, that which the legislator or the judge would have meant if he had been able to fit his meaning into the whole body of the Law. As Mr. Justice Holmes has said: "We do not inquire what the legislator meant; we ask only what the statute means." That which we call the "life" of the Law, its constant adaptation to constantly changing social conditions, is due to this objective method more than to anything else.

17. Llewellyn, supra note 5, at 7, 12-13. Cf. Holares, Collected Legal Papers (1921) 207. 
4.

"Let us assume a case not involving any doubt, but a case nevertheless which would never have occurred to anyone at the time the rule in question was established. . . . The legislator could not have intended the inclusion of this case in concreto; the case was by hypothesis not yet thought of."18

This introduces the nominalistic prejudice (in the philosophical meaning of the term). The nominalist overlooks the fact that the language of the legislator, like most language, is chiefly related to classes of things, not to individual objects. With the same right, one could oppose the application of any statute because it speaks of persons, and the litigating persons were not yet born when the statute was enacted.

5.

"The existence of an institution lies first of all and last of all in the fact that people do behave in certain patterns $\mathrm{a}, \mathrm{b}$ and c. . . . Every living constitution is an institution; it lives only so far as that is true."19

Here we have the sociological prejudice. It is not true that social phenomena can be studied by themselves without regard for the rules that govern them. Gray has given a brilliant example: "Suppose King, Lords and Commons should meet in one chamber and vote together, an order passed by them would not be obeyed by the English people." The pure sociologist could not explain this phenomenon. In the same way we may ask: Which is the institution with which Llewellyn identifies the Constitution of the United States? Is it Columbia University? Or some speakeasy? Certainly not, but the Congress is one of them. Why? Only because it acts more or less according to the rules of the Constitution. No constitutional institution can be singled out among all other institutions except against the background of the rules of the Constituion.

The sociological bias is particularly prevalent among constitutionalists who are obviously dazzled by the frequent contrast between the legal and the factual aspect of the state and the immensely greater interest attached to the latter. But I challenge any sociologist to describe, for instance, the difference between sovereign and non-sovereign states and between states and municipalities in terms of power, size, population or other factual elements. The first attempt would evince the futility of any such effort.

6.

Of the last prejudice, the professional one, examples have already

18. Correctly translated by Fuller, supra note 7, at 445, from the German of 1 LLEwELIYN, op. cit. supra note 1 , at 72,74 .

19. Llewellyn, supra note 5 , at 17. Cf. Gray, The Nature and Sources of the Law (2d ed. 1921) 76 . 
been given. The realists constantly speak of the Law as the behaviour chiefly of the judges. Why chiefly of these? Because the judges are the persons whom the attorney has professionally-directly or indirectly - to handle; and the realists are attorneys, or have been attorneys, or else they are trainers of attorneys. But if we are to speak as real realists, not as mere legalists, the behavior of every normal layman, of everybody standing in any normal jural relation to anybody else, is infinitely more important; for the great majority of these jural relations never come before the courts. We now understand why the realists, instead of focusing their attention upon the invisible certainty of the law in the normal cases, are obsessed by the obvious uncertainty of the law in the few contested cases. If they were more conscious of the logical distinctions between the legal and the sociological approach they would give full credit to the latter method and would accordingly be more interested in those phenomena which influence and shape the whole body of society, not only the functions of one important organ of it, the courts of law.

\section{The Nature of Legal Science According to the Realists}

As shedding light upon the realists' conception of the nature of legal science, the following quotations are significant:

"The prophecies of what the courts will do in fact, and nothing more pretentious, are what I mean by the law."20

". . . lawyers, like the physical scientists, are engaged in the study of objective physical phenomena. . . . As lawyers we are interested in knowing how certain officials of society-judges, legislators, and others-have behaved in the past, in order that we may make a prediction of their probable behavior in the future."21

The realists "want law to deal, they themselves want to deal, with things, with people, with tangibles, with definite tangibles, and observable relations

20. Holmes, The Path of the Law (1897) 10 Harv. L. REv. 457, 461, reprinted in Horxres, op. cit. supra note 17, at 173. This dictum of $\mathrm{Mr}$. Justice Holmes could also have been quoted supra, p. 000 of the text, as he does not distinguish between the Law and the Science of the Law. Cf. id. 10 HARv. L. REv. at 458, Hocmes, op. cit. supra, at 168: "The primary rights and duties with which jurisprudence busies itself again are nothing but prophecies." If this were true, the prophecy and the prophecied event would be the same. Cf. also, Bingham, supra note 9, at 11, 12: "His [the lawyer's] essential business is to predict these future sequences accurately ... it is a field for scientific study analogous to the field of any other science. ... [When the word law is used in the sense of 'studying law' or 'the law of property'] the speaker or writer consciously or unconsciously indicates by it causal relations of occurrences external to the mind of the observer and their governmental consequences, past or potential."

21. Cook, The Logical and Legal Basis of the Conflict of Laws (1924) 33 YArE L. J. 475. Cf. also, Oliphant, A Return to Stare Decisis (1928) 14 A. B. A. J. 159: "Not the judges' opinions, but which way they decide cases will be the dominant subject matter of any truly scientific study of law." 
between definite tangibles-not with words alone; when law deals with words, they want the words to represent tangibles which can be got at beneath the words, and observable relations between those tangibles."22

"The 'normative' conception of legal science ... precludes the objective narration of conventional legal principles by confusing law and ethics . .."23

According to these quotations, then, legal science is not a rational and normative science which tries to transform the given law into a more or less consistent system of rules. To the realists, legal science is empirical, the method of which is observation; the purpose, foretelling effects; the model, natural science. This naturalistic thesis clashes with the oldest teachings of logic as well as with modern conceptions of methodology. It is based upon confusion of categories. It will suffice to point out six of these confusions.

First of all, the realists confuse natural and cultural science. Natural science deals only with real events governed by laws of nature. Even if it should prove to be true that these laws were nothing but statistical averages, they would always remain inviolable in the sense that facts can never contradict them, since they would then cease to be laws of "nature." At the same time the harmony of observed facts with the laws of nature provides a test for the reality of the facts. But cultural sciences deal with human actions and are governed by laws of men, and these actions can be either lawful or unlawful. Indeed, they are very often unlawful, and it is precisely the existence of unlawful acts which makes legal science necessary; it alone allows us to judge unlawful acts and this presupposes the knowledge of how they ought to have been. But these unlawful acts are quite as real as the lawful acts. For this reason a natural science which knows nothing of "unlawful" and, therefore, of unreal acts, nor of unreal and, therefore, of "unlawful" acts, can teach us nothing decisive. Ours is a science which must learn to distinguish between lawful and unlawful acts, which must be able to judge the unlawful ones and therefore must previously know the unreal acts which ought to have been real. The natural science which a realist should study is that part of astronomy which might teach us how the stars ought to move, and how they move and whenever they choose to violate the laws of celestial mechanics. Unfortunately, such a branch of astronomy has not been developed, and if a person actually developed it, he would probably look to legal science for guidance, not vice versa.

Secondly, the realists confuse explanation and justification. If legal science were an empirical science, its chief method would be explanation through cause and effect. If it were a rational and normative science,

22. Llewellyn, supra note 1 , at 1223 .

23. Yntema, The Rational Basis of Legal Science (1931) 31 CoL. L. REv. 925, 945. 
its chief category would be justification through reason and consequence. Now let us approach the courts in a realistic attitude and ask which of these methods they in fact apply, for the actions of courts must be an application of legal science to a concrete question. Must a court refuse to apply a clearly worded statute if it fails to understand its historical causes or the intentions of the legislators, on the ground that a judgment based on such a statute cannot be scientifically explained? Not at all. The question chiefly interesting the judge is whether the decission he wants to give can be justified as a consequence of the particular statute, or at least as being compatible with its consequences. And what about an appellate court which has to pass on an absurd decision of the trial judge, explainable, and only explainable, by the fact that the judge was intoxicated or insane? Must his decision be upheld on the ground that it has been explained and therefore satisfies legal science? On the contrary, it will be reversed because it cannot be reasonably justified by law, and this is the only question which interests the appellate court. Genetic explanation and normative justification must be kept apart-this is one of the most important lessons of modern epistomology. It may be sense or nonsense to explain with Jerome Frank that the "childish" desire to attribute inviolable certainty to the law is caused by a "father complex"-in any case the truth or untruth of that alleged attribution is quite independent of its psycho-analytic or any other genetic explanation. Of course, the genetic method may be used as a tool in the service of the normative method and vice versa.

The third confusion is between law and ethics. This is the reproach which the realists make to the classical, normative conception. But their misgivings are entirely due to their own mistake, their confusion of legal with moral norms. The former demand some external behavior and can be complied with whatever may be the motives. The latter always take into account the motive-for instance, a selfish or altruistic aim.

Fourthly, the realists fail to distinguish between realities and their meaning. Llewellyn wishes to restrict legal science to "observable" and even "tangible" facts. Now the essential relations in law are never observable; for instance, at the same moment that a man dies in an accident without having made his will, his new born child may have become a rich man by having inherited the deceased's property without anybody knowing it. Nothing in this important legal change is in any way observable-and so it is everywhere in law. It is the meaning of observable realities with which the lawyer is concerned, but meanings are not observable, still less tangible. It is the history of law which is interested in observable and unobservable facts, and much of the research work of the Realists is indeed nothing but contemporary American legal 
history. This is one of the legal sciences and a very respectable science at that, especially if it is approached in a true sociological spirit, so that not only contemporary American facts, but also the general problem of law as conditioned by its social background is taken into consideration. But this is not the legal science of which we are speaking, the legal science which the law schools teach and which the future lawyer must learn -if for no other purpose than to influence the judge.

The fifth confusion is between the concept and one of the elements which compose the concept. If, as Mr. Justice Holmes says and all the realists repeat (as if they wished to advertise the one theory of the great judge and jurist which one would prefer not to find in his work), the law is what courts of law do, one could also say: religion is what the churches preach; science is what the universities teach; medicine is what the doctor prescribes; art is what the artist produces; and shoes are what the shoemaker makes. All this is placing the cart before the horse. One cannot define church without religion, university without science, doctor without medicine, artist without art, shoemaker without shoe, and courts of law without law. The law is not what the courts administer but the courts are the institutions which administer the law. For this reason alone can it be foretold what the courts will do. In so far as the lawyer knows the law, and in so far as the judge will follow the law, the lawyer will be able to foretell what the judge will do. The other sources of the judge's decision are in great part unknown and always will be unknown.

The last confusion is that between cases and case law. The realist movement could start and progress only in a case law country because there indeed the law seems to be a heap of decisions, and therefore a body of facts. But the cases themselves are not binding; they are not the case law; only the rationes decidendi are binding. These are-according to the controversal theory which here, of course, cannot be discussed-not the factual reasons adduced by the judge, which are only psychological facts, often based on self deception, or otherwise subject to suspicion. They are the principles from which the decisions ought to have flowed, the principles by which alone the decisions could be justified. These rationes decidendi therefore cannot simply be arrived at by an inductive process; they must be construed through purposive interpretation, they must be generalized and fitted into the whole body of the Law, which is more or less a system. ${ }^{24}$ The system into which these

24. If the Realists object to the idea of a "system" they are thinking of a "rational" system in the strict sense of the term, and in this, of course, the writer concurs. The whole free-law movement has always emphasized that the "system" which legal science tries to erect is permeated with many emotional and volitional elements. 
rationes decidendi are assimilated is the case law, and therefore something very different from a mere fact that could be the object of an empirical research. But even if it were nothing else, it would lose its meaning if there were not behind it the rule of stare decisis, whatever its limits and authority may be. Accordingly, the whole temple of case law is founded upon a rule and not upon a fact. Those who deny that rules are binding can hardly admit the binding force of precedents, which they profess to worship. Thus they destroy the Law itself.

\section{Reductio ad Absurdum}

Let us finally endeavor to know the realists by their fruits. We may first consider the startling consequences of the substantive thesis: that there is no law outside the decisions. Undecided cases could not be decided, since the respective human actions would be outside the range of the law. But every case was at one time undecided. To violate a new statute would not mean breaking the "law", nor could new statutes be interpreted, since there would be no science of law to interpret them if this science dealt with decision alone. But every statute was once a new statute. The same holds true of such parts of an old statute concerning which there are contradictory decisions. Here the decision cannot be foretold and therefore, where scientific treatment would be most necessary, it would be impossible. Certain rules which have never come before the courts, nor ever could come, would cease to be law. For instance, the rule of the Constitution that the President must be 35 years of age could not be law, and it would, therefore, not be unconstitutional to make Colonel Lindbergh President. It is futile to answer that such rules are merely sources of law. They are not "sources" in the factual sense because no decisions have flowed from them. And if one means by calling them "sources" that decisions ought to be drawn from them, one does nothing else but recognize them as rules of law. Establishment of rules by legislation would be practically useless; it would not change the jurisprudence of the courts since they are not determined by rules, or are so determined only to a small extent. The legislator, if he is not to be considered a "ruler," would be a liar: "murder is punishable by death" would mean that it is in truth punished by death. But we know that many murderers are not, because the murderers have not been caught or convicted. Why should we have learned men to decide the cases? Whatever the courts decide is the law. This may be tolerable today, because the judges have learned how they ought to decide; but a realist should not insist on their legal training. Why not staff the Supreme Court with nine generals? Surely they would know how to enforce their decisions, such a Court would "work," and that is all a realist ought to demand. 
Equally startling are the consequences of the formal theory: that the objective of legal science must be to foretell future behavior. Dissenting opinions would always be contrary to legal science, and consciously so since the dissenting judge himself knows beforehand that the prevailing opinion will be different. True, sometimes he foresees that in the future his opinion will be adopted by the Court, and then according to the formal theory both opinions would be in harmony with legal science, the dissenting as well as the prevailing. Charging a jury would involve telling it what it is about to do. This seems rather superfluous. The proper study of the law student would be the behavior of individual judges; such a study would be not only farcical but also useless. Every new generation of students would have to be taught the psychology of a new batch of judges. An essential feature of this law study of the future would be the art of bribing judges. ${ }^{25}$ In such a case the appellate court would be in a strange position. It would be compelled to say: it was foreseeable that the judge of the first instance would be bribed; his decision therefore corresponds to realistic legal science, and accordingly must be upheld. The most important task of the law schools would be to teach which citizens are going to abide by the law and which of them are going to break it. But the law schools cannot compete with inquiry offices and detective bureaus. It is their task to turn out men like Mr. Justice Holmes, not like Mr. Sherlock Holmes.

\section{Conclusion}

This article has been for the most part critical; but as was said at the beginning, that does not mean that I do not cordially appreciate the merits of the realist movement. American readers need hardly be reminded in detail what these merits are. I would merely state, with the deepest sympathy, that American realists have begun to do what European free law jurists and legal sociologists have promised to do. We Europeans have, most of us, only tuned our instruments, they have played them. Even their exaggerations have had the wholesome effect of giving a sensational touch to the movement which perhaps was necessary in order to arouse general attention. But sound methods without a sound

25. This reminds the author that many years ago he had a Russian student who was the star of Freiburg University, and especially brilliant in Roman law. He was pressed to join the faculty, but for some reason or other was forced to accept the modest post of an attorney in a Russian provincial town. After some years he wrote the writer a letter, complaining: "What is the use of all my Roman law now? The only important thing for me to know now is which of the judges can be 'fixed' and if he can't, how to 'fix' the witnesses." 
methodology are dangerous, not so much in the hands of the master as in the hands of his pupils. Here lies, it seems to me, a field for fruitful cooperation. Perhaps the present events in Germany, like the even more memorable accomplishments of the Turks in 1453, may facilitate this cooperation. Let us hope that American and German jurists may combine their specific gifts, which so happily supplement each other, in order to create the jurisprudence of the future. 